\title{
Limitations of Historical Cost Accounting Information under Inflationary Conditions:
}

\section{A Theoretical Study}

\author{
By \\ Ahmed M. Zamel \\ Professor of Accounting, faculty of commerce, Zagazig \\ University \\ Ahmed Hany Behery \\ Professor of Accounting, faculty of commerce, Zagazig \\ University
}

Dina Ali Abdelhameed Hefny

Accounting Assistant Teacher

Faculty of commerce

Zagazig University 


\section{Abstract:}

This study discusses the limitations of historical cost accounting information under inflationary conditions by introducing a review of the previous literature on inflation accounting.

The study concludes that historical-cost financial statements prepared underinflationary conditions could be misleading. Furthermore, inflation impairs the financial accounting role a basis for decision-making. Hence, the need for the adjustment of the historical cost financialstatements to reflect currenteconomic realities becomes inevitable.

يهذف هذا البحث إلى دراسة قصور المعلومات المحاسبية المبنية على أساس التكلقة التاريخية في ظل وجود التضخم، وذلك من خلال مراجعة للاراسات السابقة حول محاسبة التضخم.

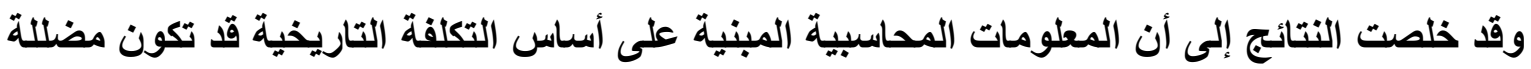
في ظل التضخم، وبالتالي فإن الحاجة إلى تعديل التقارير المالية التاريخية لكي تعكس الحقائق الاقتصادية الحالية أصبح أمراً ضرورياً. 


\section{Introduction:}

One of the most significant economic problems that have received broad attention of experts, economists and researchers over many years is inflation. Inflation is an ongoing phenomenon that has affected many economies for many years. Inflation also is referred to as price level changes.

Accounting is defined as the process of identifying, measuring and communicating economic information in order to permit informed judgments and decisions by the users of the information (American Accounting Association, 1977)

Accounting is affected by the phenomenon of inflation, which affects the accuracy of information disclosed in the financial statements. It is one of the factors that affect the accounting system in a country. Inflation, the systematic decrease of purchasing power and destroyer of wealth, is a fundamental fact of economic activity over time and creates serious financial reporting and financial management problems (Schneider et al.,1999).

Archambault and Archambault (1999) show that the rate of inflation is the dominant factor in applying inflation accounting. Countries with higher inflation rates choose to use price-level adjustment rather than historical cost with some revaluations.

The accounting financial reporting regime is nominal, which assumes no changes to the purchasing power of money over time.Although the effects of inflation on financial reporting received considerable attention during the late 1970s when inflation was relatively high, inflationary effects have been mostly ignored in the more modest inflationary environment since that time (Konchitchki, 2011). 
Financial statements without adequate adjustment to inflation do not reflect appropriately the financial position and performance of business enterprises. Furthermore, unadjusted financial statements can be meaningless or even misleading under inflationary conditions.Several countries have implemented different adjustment procedures resulting in lack of uniformity. A uniform solution to the problem of assessing financial performance of enterprises in an inflationary environment has been long overdue (Goldschmidt and Jacob, 1991).

A number of articles have beenpublished, but findings have not been conclusive and decisive. The fundamental arguments against accounting for price changes are that the orthodox of conservatism and historical costs must be the foundation for financial reporting. The so-called attribute of reliability derived from historical costs must be emphasized in various spectrums. The arguments for taking account of inflation seek to enhance more the relevance attribute of accounting reporting, in order to reflect more accurately the current economic values of assets (Du and Min, 2012).

\section{Problem Statement:}

The objective of financial information is to provide users with relevant and timely information for decision-making. While decisionmaking is concerned with future actions, the infrastructure which generates accounting information as frame worked by Generally Accepted Accounting Principles (GAAP) is based on historical cost. This is fundamental accounting practice, as evolved over the years, has proved to be reasonably satisfactory during the periods of relative price stability. However, in the absence of price stability, which is often the case in many developing countries, the value of accounting information as a practical language of economics could be lost and its quality of being relevant for decision making damaged (Bello, 2011). 
High quality accounting information is of key importance for a large number of users, as it influences the quality of their decisions. Providing high quality and useful accounting information is a prerequisite for the efficiency of the enterprise. The usefulness of the accounting information is connected with the extent to which this information corresponds to the particular needs at any given time and how the information contributes to the solution of a particular problem. Usefulness is determined by the quality of accounting information. By useful information which means the kind of information that is necessary and needed by its users; is provided on time and is used for performing a particular activity and for the implementation of direct or indirect link/feedback between the preparers and the users of accounting information. Measuring and assessing the quality and usefulness of accounting information are of particular importance, as these activities will not only enhance the quality of economic decision-making for the users, but also the overall market efficiency of the business as well (Tsoncheva, 2015).

The International Accounting Standards Board issuedstandards as well as the conceptual framework, essentially aiming at producing higher quality financial statements. The critical question that arises is whether this goal has been achieved; that is, whether the historical financial statements following the IASB adoption are in fact, of higher quality as opposed to inflation adjusted financial statements.

In periods of rising prices, financial accounting information has been criticized because it reflects a number of dated monetary units while the value of the monetary unit is changing. According to Hughes, et al. (2004), "Inflation, creates an earnings illusion as an artifact of the mismatching of expenses based on allocations of historical costs with current revenues in determining earnings. This mismatching distorts mappings of aggregate 
earnings and book values into equity value such that value-relevant information is lost."

Manyarguments have been presented that under conditions of changes in the general level of prices financial statements are irrelevant and uninterpretable. According to the argument for restatement of financial statements, a real (constant) money measure of performance indicates that management is failing to maintain its physical stock of capital. The nominal money measure is considered to be the problem, since it cannot provide a constant measure of the physical quantities. Attempts have been made to alter financial accounting information in order to measure the impact of inflation on a business enterprise to assist the firm in making its investment decisions and the firm's shareholders in making their investment and consumption decisions.However, in great part, these attempts have not withstood the test of relevance and interpretability. The argument in support of accounting for changes in the general level of prices was examined in light of the following questions: What is it that is entrusted to management? Is it a physical stock or a financial stock of capital? Does a firm seek to accumulate a physical stock or a nominal money stock? Are the suppliers of money-capital concerned with physical flow prediction or with nominal money flow prediction? (Stanley, 2004).

In recognizing the defects of financial reports in inflation situations, a lot of debates, observations, reservations and opinions were presented in economies such as the U.S and the U.K. However, in developing economies, like Egypt, where inflation is more persistent and is likely to remain so in the near future, little effort has been made.

This studyexamines the limitations of historical cost under inflationary conditions. 


\section{Research Objective:}

The main objective of this research is to discuss the limitations of historical cost accounting under inflationary conditions.

The reminder of this paper presentsmeaning of inflation,history of inflation in Egypt, limitations of historical cost accounting system under inflationary condition and conclusion.

\section{1- Meaning of Inflation:}

Inflation affects everything in our life, from basic necessities like housing, food, medical care, education and utilities to the cost of luxuries goods and services. In addition, inflation has negative effects on our savings. It makes money saved today less valuable tomorrow, eroding our future purchasing power and even interfering with our ability to retire.

Inflation is a rise in the general level of prices of goods and services in an economy over a period. An increase in the general price level makes each unit of currency buys fewer goods and services .Consequently, inflation is erosion in the purchasing power of money. A chief measure of price inflation is the inflation rate. Inflation rate is the percentage change in a general price index or the rate at which the general level of prices for goods and services is rising (Islam, 2013).

Labonte (2011:p.1) defined inflation as a sustained or continuous rise in the general price level or, alternatively, as a sustained or continuous fall in the value of money. Several points should be noted about this definition:

- First, inflation refers to the movement in the general level of prices. It does not refer to changes in one price relative to other prices. These changes are common even when the overall level of prices is stable.

- Second, the prices are those of goods and services. 
- Third, the rise in the price level must be somewhat substantial and continue over a period longer than a day, week, or month.

From the above definitions, Inflation can be defined either as a rise in prices,decrease in the monetary value or as an expansion in aggregate income (expenditure). Inflation is a state of disequilibrium when there occurs a sustained rise in price level. It is inflation if the prices of most goods go up.The rate of increase in prices may be slow, moderate or rapid.

\section{2-History of Inflation in Egypt:}

The essential goal of macroeconomic policies in Egyptis to keep inflation low, stable and predictable as it can as possible. However, data shows that this is merely an objective and has not often been achieved. During the study period (2014-2018), the Egyptian economy has witnessed substantial economic and political changes. These changes have affected the inflation- rates in Egypt.

Inflation rates were in general relatively high during the 1980s before dropping substantially in the 1990s after the adoption of the Economic Reform and Structural Adjustment Programme. Afterwards, inflation rates started to increase once again reaching $18 \%$ in 2008 compared to $2 \%$ in the year 2001.In the new millennium, Egypt continued in adopting economic reform policies in several areas such as foreign exchange rates, taxes, and banking systems. In 2003, a managed floating exchange rate system came into effect to replace the old system that pegs the Egyptian pound against the US dollar. This flexibility in the exchange rate was intended to achieve price stability and reduce the inflationary pressures by correcting for the overvaluation of the Egyptian pound and to face the growing black market for currency, all of which will enhance the competitiveness of the Egyptian exports. Following the new floating system, 
the Egyptian pound depreciated by around 25\%. However, the depreciation of the Egyptian pound seems to have contributed rather than to remedy the increase in the inflation rate given the high dependence on imports to satisfy domestic demand for most of the essential goods. Despite the undertaken policy reforms, inflation rates increased significantly during this period, reaching $11 \%$ in 2004 and $19.1 \%$ in 2008(Sharaf,2015).

Inflation rate declined only in 2005 . It reached $4.8 \%$ but this decline happened after the central bank declared that the inflation targeting regime will be adopted. So the central bank will target an inflation rate and then it will try to steer actual inflation towards the target through the use of interest rate changes and other monetary tools. but it returned to rise to $9.5 \%$ in $2007 / 2008$ and reached $18.3 \%$ in $2008 / 2009$ as the result of supply shocks resulting from high food and energy prices and other services on one hand and demand pressures particularly in the construction sector This high inflation pressures lead to decrease the real income and so the ability of peoples to get their basic needs was affected.The Egyptian revolution on January 25, 2011 was a transformative event, both at the political and economic domains, resulting in long lasting and wide implications which include increase in annual inflation rate to more than $12 \%$ in 2012 compared to $10 \%$ in 2010 . In 2013,2014 and 2015 inflation rate ranged from $10 \%$ to $12 \%$.Inflation was already on the rise in 2016, having accelerated to around 14\% by October 2016 (NBK Economic Research,2017).

On November 3, 2016, the Egyptian government officially floated the national currency, following through with a key demand of the International Monetary Fund (IMF). It also responded to pressure from the black market, where the Egyptian pound had plunged to a record low of 18 to the dollar, less than half of the official rate. Prices for imported goods have since surged, adding to the inflationary pressures created by the slashing of subsidies and 
new consumer taxes. Within less than a year, a large part of the Egyptian population has seen half of its real purchase power wiped out (Stiftung,2017).

The liberalization of the exchange rate regime and the devaluation of the Egyptian pound were critical steps toward restoring confidence in the economy and eliminating foreignexchange shortages. The new exchange rate regime will be supported by prudently tight monetary policy to anchor inflation expectations, contain domestic and external demand pressures, and allow accumulation of foreign exchange reserves. On November 11, 2016, the Executive Board of the International Monetary Fund (IMF) approved a threeyear extended arrangement under the Extended Fund Facility (EFF) for the Arab Republic of Egypt for an amount equivalent to US\$12 billion, to support the authorities' economic reform program(IMF,2016).

Annual headline inflation rose to 28.14 percent in January 2017 due to exceptional monthly increases averaging 4.01 percent between November 2016 and January 2017 that were strongly impacted by the economic reform measures. The higher monthly inflation in January (4.07 percent) compared to December (3.13 percent) is estimated to be partly driven by relatively higher regular monthly dynamics as well as the introduction of higher custom tariffs at the end of 2016(Central Bank of Egypt, 2017).By the end of 2017, inflation rate reached to 29.5 percent. At the end of 2018 inflation rate declined to $14.5 \%$.

As illustration, figure 1 summarized the annual inflation rate for Egypt for the period from 2008 to 2018. 


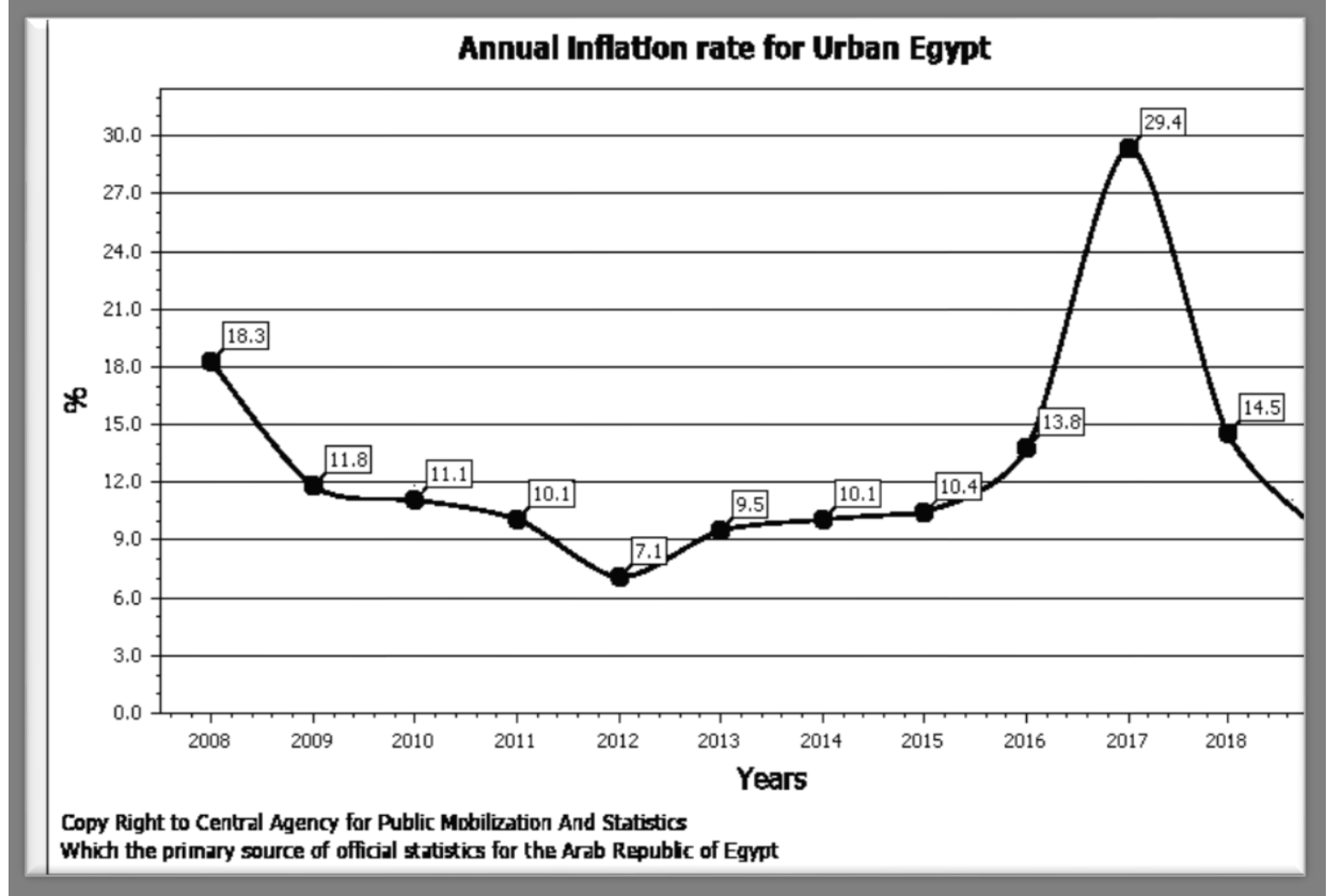

Figure 1: annual inflation rate in Egypt (2008-2018).

\section{3-Limitations of Historical Cost Accounting under Inflationary Conditions:}

The traditional assumption of stable currency and historical cost accounting model considers neither changes in monetary value nor price changes of measured production factors; therefore it cannot reflect the information of price changes.The Financial Accounting Standard BoardFASB (1979) stated that the absence of information about the effects of changing prices could lead to the following difficulties:

'Resources may be allocated inefficiently, investors' and creditors' understanding of the past performance of an enterprise and their ability to assess future cash flows may be severely limited." (Paragraph 3: p. 2) 
In the case of inflation, the use of historical cost accounting will lead to the following serious limitations:

- The accounting financial reporting regime is nominal, which assumes no changes to the purchasing power of money over time. That is, the accounting amounts reported in financial statements are called nominal because they are not adjusted for inflation. When purchasing power is not constant, a nominal reporting system that combines monetary amounts from different periods violates the Monetary Unit accounting assumption of a stable currency (SFAC 5, Financial Accounting Standards Board, FASB 1984) and decreases comparability both across firms and over time (Konchitchki, 2011). Comparability of business entities, which is so necessary in the assessment of performance and growth, becomes distorted.

- Financial reports become confusing at best, misleading at worst, because revenue is mismatched with differing historical cost levels as the monetary unit becomes unstable (Elliott ; J. Elliott,2011).

- Using The nominal financial reporting regime result in two types of accounting errors which include (Sherazy,1990):

a) Measurement errors: Ignoring the changing purchasing power of money (Monetary Unit accounting assumption of a stable currency) makes the accounting numbers non-additive and non-comparable.

b) Timing errors: Whichresult from delaying the recognition of changes in value until the objective evidence is available (traditional formof realization principle).

- Financial statements without adequate adjustment to inflation do not reflect appropriately the financial position and performance of business enterprises. Furthermore, unadjusted financial statements can be meaningless or even misleading under Inflationary conditions. The FASB 
(1979) stated that the absence of inflation accounting information could lead to the following difficulties:

"Resources may be allocated inefficiently, investors' and creditors' understanding of the past performance of an enterprise and their ability to assess future cash flows may be severely limited." (Paragraph 3: p. 2)

- Unadjusted financial statements overstate profitability during a period of rising prices, and misrepresent the relative financial strengths of firms. The concern is that analysts and investors cannot make informed financial decisions without understanding the impact of inflation on financial information (zaid,2013).

- Since depreciation charges forlong-lived assets do not reflect the current costs, accountskept in historical units overstate income. If the inflationrate is high enough, even the costs which are incurred in thesame year when they are expensed do not reflect the currentjcosts. On the other hand, revenue increases as prices rise. Thus, an overstated income results. In addition to the overstatement of income, understated book values of assetscompound the effect upon the rate of return on capital.In parallel to the overstatement of income, the effectivetax rate also increases. Since income tax is determined as apercentage, it goes up with reported income. However, realincome may not have increased at all. As a result, theeffective tax rate, tax as a percentage of real income,becomes larger.Another issue is the maintenance of business capitalrepresented by stockholders'" equity. Basically, income isdivided among tax, dividends and retained earnings. Asillustrated above, the effective tax rate increases underinflation and takes a greater portion of income. On the otherhand, stockholders expect to receive enough dividends to makeup for inflation. However, if sufficient earnings to maintainthe physical capital are not retained, dividend policies basedon 
overstated income figures may erode the capital base. Physical capital represents the resources necessary to maintain the existing level of productive capacity (Wadi,2006).

- Under inflationary conditions, however, the purchasing power of the money declines, causing some crucial figures of the conventional financial statements especially net income and nonmonetary assets' value to be distorted. Thus, "a hundred feet plus ten centimeters is certainly not a hundred and ten anything, and the accountant's balance-sheet total is not much better". In other words, during a period of inflation, the values of assets and some cost items (such as depreciation of fixed assets), as recorded in the financial statements, tend to be understated. To provide meaningful information, these figures should be revalued (Goldschmidt and Yaron,1991).

- Nominal financial statements, by their nature, do not account for gains and losses attributable to changes in purchasing power over time. For example, whereas the erosion of a firm's monetary assets (e.g., cash) attributable to inflation is a loss to the firm, the erosion of a firm's monetary liabilities (e.g., debt) is a gain. Further, whereas inflationadjusted amounts of nonmonetary items (e.g., land) accumulate inflationary effects over time to reflect changes in purchasing power, such effects are not recognized in nominal financial statements. The difference between inflation-adjusted and nominal earnings represents unrecognized gains and losses from inflation (Konchitchki, 2011).

- Inflation decreases the effectiveness of financial reports by not only creating wrong effects about the potentials of company's profits and losses but also it leads to incorrect managerial decisions about profit distribution, product pricing and performance evaluation (Nemr, 1986).The decision-making process, the formulation of plans and the 
setting of targets may be suboptimal if the financial base data are out of date.

- The failure of accountants' to recognize, identify, measure, and report the effects of price changes has contributed to the measurement problem and diminished the relevance attached to accounting information as a vehicle as well as an infrastructure for financial decisions. As decisionmaking involves future actions, accounting information reported under historical cost reflects a mere historical numbers of the past (Bello,2011).

In the same context, the credibility of accounting information may be affected by inflation at leastat these four main appearances (Shaban, 1986):

- Incredibility of historical values which are included in the balance sheet:

According to the traditional accounting methods, assets and liabilities are presented in pecuniary form and the monetary unit is used as the unit of measurement. As a result, the balance sheet present an idea about the adequacy of assets to reimbursing liabilities, but it does not give adequate information about the real values of these assets.

- Incredibility of Profit or Profit Illusions:

Revenues that are measured by a monetary unit that has current purchasing power will be matched by costs that are measured by a monetary unit that has different or higher purchasing power, and as a result, the profit will be overstated.

- Capital Erosion:

Some companies may consider their historical profits as a distributable income and consequently distribute it after paying taxes, so they distribute part of capital which will result in capital erosion. 
- Ignoring the effect of inflation on borrowing and drawing structure:

During inflation a company's monetary assets and monetary liabilities lose real value. A company with net monetary assets suffers a loss in real terms, the company with net monetary liabilities makes a gain, as less real cost is involved in paying debt. Thus, a high gearing company gains handsomely from inflation.

\section{4-Conclusion:}

Debate about inflation accounting has been ongoing for many years in many countries, especially the developing countries. This study tries toshift attention to inflation accountingapplication by investigating the limitations of historical cost accounting information under inflationary conditions.

The overall findings of previous studies concluded that historical-cost financial statements prepared in inflationary conditions could be misleading. Furthermore, it reduces the financial accounting role as an input for decision-making. Hence, the need for adjustment of the historical cost approach to reflect current economic realities becomes inevitable.

Further research should be conducted regarding the following issues:

- The effect of inflation accounting on key financial ratios.

- The usefulness of inflation-adjusted data in bankruptcy prediction and distribution of dividend decisions.

- The ability of inflation-adjusted information to improve financial reporting quality. 


\section{References}

Translated from Arabic References:

Nemr, N. M. 1983. A study of the impact of economic inflation on the accounting thought and proposed model for inflation accounting. Social Science Journal11(4).Council of Scientific Publication. Kuwait University.

Shaban, H.A. 1986. Credibility of accounting information in light of inflation.Business Research Journal 8(9,10) :127-148, Faculty of Commerce, Zagazig University.

Sherazy.A.M.1990.Accounting Theory. Zat Al-salasel .First Edition Wadi, M. F. A. 2006.The effect of inflation on accounting disclosure in Palestinian economic bodies. A published Master Thesis, Faculty of Commerce, Islamic University- Gaza.

References in English:

American Accounting Association (1977), Concepts and Standards for External Financial Reports - Statement on Accounting Theory and Theory Acceptance.

Archambault, J. J. and M. E. Archambault. 1999. A cross-national test of determinants of inflation accounting practices. TheInternational Journal of Accounting 34(2) :189-220.

Bello, A. 2011.The Joint Information Content of General Purchasing Power and Current Cost Accounting.Retrieved at August 22,2017, from:https://www.researchgate.net/publication/228270005_ The Joint Information Content of General Purchasing Power and Current Cost Accounting.

Central Bank of Egypt .Press Release February 16, 2017.

Du, J. andC. Min. 2012 .Can inflation-adjusted financial statements improve accounting reporting quality? An emerging market case.Retrieved at July 20,2015, from: http://www.wbiconpro.com/103-Jonathan.pdf. 
Elliott,B. Elliott,J. 2011.Financial Accounting and Reporting.Fourteenth Edition.Retrieved at December 15,2016,from:http://www.pearsoned.co.uk. Financial Accounting Standards Board, Statement of Financial Accounting Standards No. 33 Financial reporting and changing prices, Stanford, CN: FASS, 1979.

Financial Accounting Standards Board. 1984. Statement of Financial Accounting Concepts No. 5: recognition and measurement in financial statements of business enterprises. Norwalk, Connecticut.

Goldschmidt, $Y$ and J. Yaron .1991.Inflation adjustments of financial statements application of international accounting standard 29. Working Paper, Retrieved at September 30, 2016, from:http://wwwwds.worldbank.org/servlet/WDSContentServer/WDSP/IB/ 1991.

Hughes, J. et al. 2004. Valuation and accounting for inflation and foreign exchange. Journal of Accounting Research42(4): 731-754.

International Monetary Fund Washington, D.C. 20431 USA Press ReleaseNo.16/501 for Immediate Release November 11, 2016. www.imf.org. Islam,A.2013.Impact of inflation on import: An empirical study.International Journal of Economics, Finance and Management Sciences1(6):299-309.

Konchitchkis, Y. 2011. Inflation and nominal financial reporting: implications for performance and stock prices. The Accounting Review 86(3):1045-1085.

Labonte,M.2011. Inflation: causes, costs, and current status. Congressional Research Service. Retrieved at October 9,2016,from:https://pdfs.semanticscholar.org/.../7bf4dd4a6c9bce7c0572250627 $\underline{43}$.

NBK Economic Research. 2017. Egypt: Painful reforms and IMF loan should support gradual recovery. Retrieved at March 22, 2017, from: http://www.nbk.com. 
Schneider, W.P. et al. 1999. Price-level changes and financial reporting: a discussion of the consequences of the FASB'S failure to consider the effect of price-level changes on the determination of comprehensive income. Retrieved at March 14,2015,from: web. calstatela. edu. faculty .

Sharaf, M.F. 2015. Inflation and Inflation Uncertainty Revisited: Evidence from Egypt. Economies 3: 128-146, Faculty of Commerce. Damanhour University, Egypt.

Stanley, C. W. S. 2004. Price level changes and financial accounting measurement. Retrieved at June 15, 2016,from:http: //ssrn. com/abstract $=689821$ orhttp: $/ /$ dx.doi. org $/ 10.2139 /$ ssrn. 689821 .

Stiftung , H.B. 2017. Policy Brief Egypt 3 - Economy the Political Side of Egypt's Economic Ordeal. E-Paper. Retrieved at March 4,2018, from: https://tn. boell. org/sites/default/.../policy-brief-egypt-3_economy. pdf. Tsoncheva, Z.T. 2015. What Causes Inflation in the United States. Zaid, A. 2013.The Value Relevance of Inflation Accounting Disclosure of Quoted Petroleum Firms in Nigeria. Retrieved at: May 3, 2016, from: https://www.reseasrchgate.net. 